\title{
15. ORIGIN, REBURIAL, AND SIGNIFICANCE OF A MIDDLE MIOCENE CANYON, NEW JERSEY CONTINENTAL SLOPE ${ }^{1}$
}

\author{
G.S. Mountain, ${ }^{2}$ J.E. Damuth, ${ }^{3}$ C.M.G. McHugh, ${ }^{4,2}$ J.M. Lorenzo,${ }^{5}$ and C.S. Fulthorpe ${ }^{6}$
}

\begin{abstract}
Ocean Drilling Program Site 906 was drilled through a 5-km-wide, buried slope canyon to learn when and how this feature formed, was maintained, and subsequently filled. Seismic profiles show that it is the oldest Neogene canyon in the region, and that it marks the beginning of major slope bypass that continued intermittently to Pleistocene time. Sampling the oldest material within the canyon (pre-reflector $\mathrm{m} 2$ ) to determine the minimum canyon age, and tracing the youngest surface cut by the canyon to a nearby site (reflector $\mathrm{m} 3$ ) to determine the maximum age, shows the canyon formed between $13.5 \pm 0.5$, and $12.4 \pm 0.5$ m.y.

The first sediment that accumulated within the canyon is a 57-m breccia deposit shed from the adjacent walls; matrix-supported debris flows of similar age and lithology were sampled at Site $905,52 \mathrm{~km}$ southeast at $2800-\mathrm{m}$ water depth on the continental rise. At both sites this material lacks shallow-water sand, and together with the flat (not V-shaped) canyon cross-section cutting into reflector $\mathrm{m} 3$ suggests that the canyon formed sometime after $13.5 \pm 0.5 \mathrm{~m} . \mathrm{y}$. as a result of sediment failure that widened and lengthened the scar during headward erosion. By this process the canyon connected with a sediment source on the adjacent shelf, probably in less than $\sim 0.5 \mathrm{Ma}$, and $60 \mathrm{~m}$ of mostly quartz sand turbidites accumulated above the Site 906 breccia; no equivalent turbidites have been found outside the canyon.

Reflector $\mathrm{m} 2$ (12.4 $\pm 0.5 \mathrm{~m} . \mathrm{y}$.$) is the oldest seismic reflector draping both the canyon and the adjacent slope, and it matches$ the top of an 82-m unit of laminated siltstone at Site 906. Seismic mapping beneath the upper slope shows this laminated unit completely filled the canyon $5 \mathrm{~km}$ landward of Site 906; furthermore, this unit lapped out against the basal breccias and turbidites just $7 \mathrm{~km}$ seaward of Site 906, demonstrating the head of the canyon filled first. This left a $250-\mathrm{m}$ high, headless canyon on the middle and lower slope that has subsequently been utilized and completely filled by overlying canyon systems. Younger Miocene canyons seen in nearby profiles reveal a similar history.

This evidence emphasizes that sediment failure and headward erosion are important precursors to shelf-edge sands finding a ready conduit to the deep sea. Sea-level fall can thus be a secondary process in slope canyon formation. Because canyons are buried on the upper slope before those on the lower slope, canyon piracy is more common in the latter setting. Consequently, the stratigraphic record of lower slope canyons can be especially complex.
\end{abstract}

\section{INTRODUCTION}

\section{Neogene Canyons Buried on the New Jersey Slope}

The unexpectedly early termination of operations at Ocean Drilling Program (ODP) Site 905 (Shipboard Scientific Party, 1994a) placed the remainder of our drilling expedition at a crossroads. We had neither the safety clearance nor the time to attempt a second deep penetration on the upper rise, and the blanket of Pleistocene debris flow sediments at Site 905 excluded any thought of there being added benefit to shallow holes on the upper rise. With several options before it, the shipboard party chose to return to the slope and attempt to recover sediments lining what appeared in site-survey profiles to be the oldest of several buried Neogene canyons.

While beginning the tie-in survey for Site 906 (Mountain et al., 1994), we were confident that one of the fundamental objectives of Leg 150 had already been met at Sites 902-904: we had recovered sediments that correlate to many of the seismic reflections that we

Mountain, G.S., Miller, K.G., Blum, P., Poag, C.W., and Twichell, D.C. (Eds.), 1996. Proc. ODP, Sci. Results, 150: College Station, TX (Ocean Drilling Program).

${ }^{2}$ Lamont-Doherty Earth Observatory, Columbia University, Palisades, NY 10964. U.S.A. mountain@ldeo.columbia.edu

${ }^{3}$ Earth Resource and Environment Center, Department of Geology, University of Texas at Arlington, Arlington, TX 76019, U.S.A.

${ }^{4}$ Department of Geology, Queens College, City University of New York, Flushing, NY 11367, U.S.A

'Department of Geology and Geophysics, Louisiana State University, Baton Rouge, LA 70803, U.S.A.

${ }^{6}$ Institute for Geophysics, University of Texas at Austin, Austin, TX 78759, U.S.A. could trace to sequence boundaries on the adjacent shelf (Greenlee and Moore, 1988; Greenlee et al., 1992; Miller and Mountain, 1994). Future shelf drilling will determine the crucial facies changes across and along these stratal surfaces, but the participants on Leg 150 had completed the important first task of determining these ages to the greatest degree possible. Relatively little time is missing across these key seismic reflections beneath the slope. As suspected on the ship, and borne out by subsequent shore-based analyses (Miller et al., this volume), Sites 902-904 collected nearly intact records of slope sedimentation from the mid-Oligocene to the upper Miocene. Our reason for going to Site 906 was different-we now wanted to determine at what times and by what processes material had been either removed from or bypassed the slope during a sequence of submarine canyon formation, maintenance, and subsequent reburial. Hence, at this site we planned to concentrate on surfaces that would run the risk of turning out to be very lengthy and rather unrevealing hiatuses. Fortunately, we were equipped with excellent site-survey profiles and the means to acquire a few more tens of miles of critical profile data to optimize the site location.

We knew from the experience at Site 612 (Deep Sea Drilling Project [DSDP] Leg 95; Poag, Watts, et al., 1987) that drilling to determine the history of buried canyons had a high chance for success. On that occasion, a middle/late Miocene canyon was drilled inadvertently, but core recovery and biostratigraphic age control were sufficient to determine that the canyon was cut into lowermost Oligocene carbonate sediment and was filled with middle/upper Miocene siliciclastics. Unfortunately, the more nearly complete section adjacent to the buried canyon was not sampled, and it was impossible to deter- 
mine the time of incision with certainty. Circumstantial evidence, however, was assembled to argue for a cut-and-fill sequence restricted entirely to the late Miocene (Miller et al., 1987).

Tracing reflectors from where they had been drilled and dated at Sites 902-904 confirmed that the canyon at Site 612 was indeed cut during the late Miocene. However, Leg 150 drilling distinguished lower from middle Miocene sediments in terms of accumulation rate, composition, and reflector geometry, and suggested to us that canyons slightly older (probably middle Miocene) than the one at Site 612 were to be found in the Leg 150 area of operations. Specifically, Sites 902-904 (Mountain, Miller, Blum, et al., 1994) indicated that sedimentation rates between the early and late Miocene increased from roughly 10 to $40 \mathrm{~m} / \mathrm{m}$.y. or more. Further, terrestrial organic matter (estimated visually in smear slides and measured by pyrolysis) was generally undetectable in the Oligocene and lower Miocene, but became a noticeable component in the middle Miocene. These facts are consistent with the simple observation that Neogene clinoform wedges, easily seen in profiles prograding across the shelf (Schlee, 1981; Greenlee and Moore, 1988; Greenlee et al., 1992; Miller and Mountain, 1994) and confirmed in accumulation rates and sediment distribution (Poag, 1985; Poag and Mountain, 1987; Poag and Sevon, 1989), did not reach the upper slope until the late Miocene. Terrestrial, river-borne sediment remained predominantly on the shelf before that time. It appeared that as an additional consequence, no major canyons were cut into the continental slope during the Oligocene through early Miocene.

\section{Objectives of Site 906 and of This Paper}

Our goal at Site 906 was to drill into the Neogene canyon that we judged to be the oldest one visible in site-survey profiles. A grid of data revealed the best candidate was a fairly wide $(5 \mathrm{~km})$ and deep $(250 \mathrm{~m})$ feature now buried a few hundred meters beneath the slope a few kilometers north and east of the other Leg 150 sites. We conducted a short tie-in survey (Mountain et al., 1994; Fig. 1) that pinpointed a location that would allow us to take advantage of the Pliocene-Pleistocene cover stripped off by the modern Berkeley Canyon and reach the axis of the buried canyon as quickly as possible. Hence, we drilled directly into the floor of one canyon to reach the floor of another. Along the way we drilled into a smaller latest middle Miocene canyon that probably formed close to the same time as the one at DSDP Site 612.

Site 612 had shown that sampling the oldest canyon fill provided only one-half of what was needed; without firm age control on sediments adjacent to the canyon, its history was still largely unknown. It was imperative at Site 906 that we have good control on the age of the oldest canyon fill as well as the youngest sediment into which the canyon was cut. It appeared that this strategy could be met ideally by a buried canyon on multichannel seismic profile 1027 , about $3.5 \mathrm{~km}$ north-northeast of Site 902 (Fig. 1). In this profile it was clear that the target canyon was cut into reflector $\mathrm{m} 3$ (Fig. 2), and was almost entirely filled by strata older than reflector $\mathrm{m} 2$. Sediments bracketed by both of these reflectors were sampled at Sites 902-904 (Mountain, Miller, Blum, et al., 1994.)

We were fortunate to have not chosen to drill this same canyon farther downslope. As will be discussed, profiles show that the canyon filled first in its upslope region, and that the difference in age between cut and fill consequently widens downslope. For example, had we drilled just $7 \mathrm{~km}$ southeast, still within the buried canyon, the oldest sediments resting on the canyon floor would have been stratigraphically above reflector $\mathrm{m} 2$, and younger than the basal fill at Site 906 by one to several million years. On the other hand, profiles across the target canyon farther upslope indeed show a thicker pre-m2 section, but nowhere have we seen evidence that strata as old as reflector $\mathrm{m} 3$ lie within this canyon; the longer drilling times we would have endured farther upslope would not have improved our understanding of this canyon's history. It appears that Site 906 was ideally located to enable us to reach meaningful goals in the time remaining on our Leg.

Hence, the goal of Site 906 was met with both careful planning and with some degree of good fortune. It provided critical control of both age and facies relationships that has allowed us to address the issues we discuss in this paper: When did this canyon form? How did it form? How long was it a conduit for sediments to bypass the slope? By what depositional process(es) did it become buried? What does its history reveal about the advance of clinoform packages across the adjacent shelf and the related issue of relative sea-level change?

\section{BACKGROUND}

Despite the length of time that modern slope canyons have been known to marine geologists (Dana, 1863), their origin remains a matter of considerable uncertainty. The accurate interpretation of marine survey data places stringent demands on the reliability of navigation, sample depth, and seismic correlation, and the occasional lack of adequate precision has certainly contributed to the present level of debate. Furthermore, it is clear that no single, grand model accounts for the origin of all canyons, and that at times any of several factors can affect these features (Shepard, 1981). Two general explanations of canyon formation exist: abrasion by sediment mass movement that starts near the shelf break and extends the canyon seaward, and sediment failure that begins on the slope and by headward erosion lengthens the canyon landward.

The "top-down," abrasive model appealed to early mappers because of the morphological similarities between submarine canyons and fluvial systems. Given Pleistocene ice-volume changes of sufficient magnitude it was reasonable to think that ancient rivers flowed across continental shelves and cut their graded profiles into the upper continental slope (Spencer, 1903). In this view, the modern slope was merely a drowned drainage system. But this model became highly suspect as marine surveys began to reveal canyon systems in water depths far below any reasonable reach of lowstand rivers. Work in both flume and field studies resurrected the model, however, with the discovery that turbidity currents could extend the erosive power of Pleistocene rivers far beyond their primary sediment distribution points (Daly, 1936; Kuenen, 1937). Furthermore, it was recognized that canyon erosion and intercanyon buildup could continue even as ancient shorelines moved back across the shelf, with the result that canyons could become deeply entrenched on the slope (Shepard, 1981).

Buried Pleistocene valleys of the Hudson and Delaware Rivers have indeed been traced across the shelf (Ewing et al., 1963; Twichell et al., 1977; Knebel et al., 1979; Davies et al., 1992), and clearly they once transported sediment to the heads of the Hudson and Wilmington canyons. Daly's (1936) model has been substantiated further by the recovery of turbidites on the Hatteras Abyssal Plain that are similar in composition to the relict sands found near the heads of slope canyons off the mid-Atlantic states (Horn et al., 1971).

High-precision surveys of the last two decades, however, have provided support for the competing, "bottom-up," retrograde failure model of canyon formation. Studies off New Jersey (Robb et al., 1981; Twichell and Roberts, 1982; Farre et al., 1983) have revealed a large number of small (tens of meters deep, hundreds of meters wide), relatively straight canyons that begin entirely on the slope. It is proposed that these are slump scars whose retrograde growth has not yet reached the shelf edge. Farre et al. (1983) proposed a twostage history to canyon formation, of which these small features are the first. The second, mature stage begins when headward erosion connects a canyon with a source of shelf-edge sands, and turbidity 


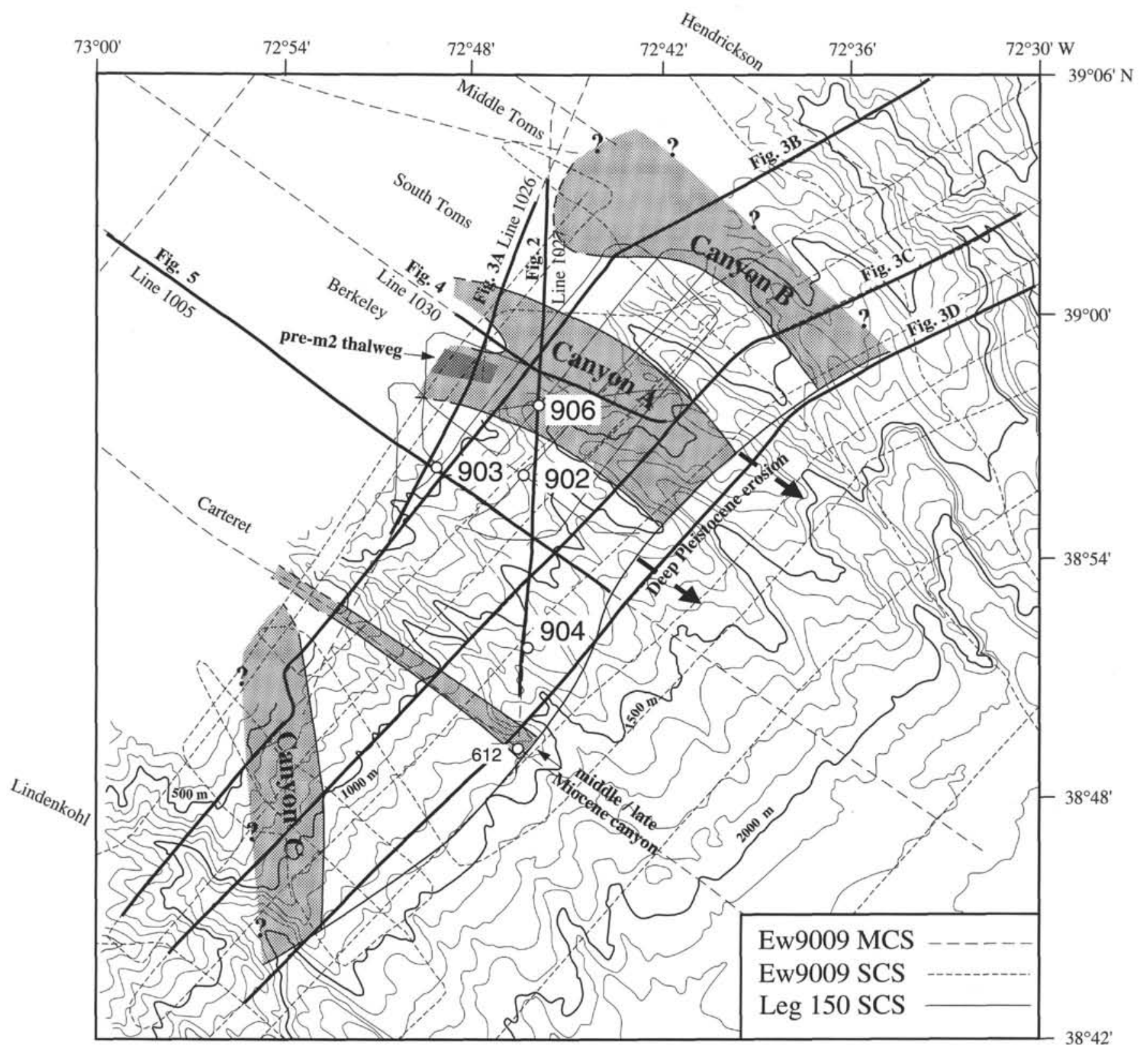

Figure 1. Location map of drill sites (ODP Leg 150 Sites 902, 903, 904, and 906; DSDP Leg 95 Site 612) and seismic profiles (Ew9009 MCS Lines 1003, 1005, 1006, 1026, 1027, 1030; unnumbered Ew9009 SCS lines; ODP Leg 150 SCS Line 3) used in this report. Bathymetry is based on SeaBeam (Pratson et al., 1994). Modern canyons are labeled; the locations of buried Neogene canyons "A," "B," and "C" (see text) are indicated.

currents become the dominant agent in canyon development. Turbidity currents in this view simply utilize depressions that were formed by some earlier process.

These studies off New Jersey and elsewhere (e.g., Scanlon, 1982) have shown further that sediment failure is not restricted to the heads of canyons: "tributary gullies" incise the flanks of canyons in a trellis-like pattern, and are themselves eroding intercanyon areas (Farre et al., 1983). Some systems are so dense that gullies from adjacent canyons meet in sharp-crested ridges (Twichell and Roberts, 1982; Shor and McClennen, 1988). The absence of debris at the junction of gullies and the canyon into which they lead has been cited as evidence that these canyons are being flushed by Holocene turbidity currents (McGregor et al., 1982), and suggests that efficient downslope transport is occurring at present.
Pratson et al. (1994) have recently swung the debate back over in favor of the top-down model. They acknowledged that headward erosion occurs off New Jersey, but note that it is largely restricted to jointed and fractured Eocene outcrops on the lower slope. More importantly, their morphologic data shows that small, upper slope canyons typically coalesce into wider, deeper confluences on the middle to lower slope. If these features were formed solely by headward erosion, it is difficult to explain how a developing canyon could bifurcate as it grows upslope. Pratson et al. (1994) examined the spatial relationship between exposed and buried canyons, and found that preexisting canyons, either partially or wholly filled, commonly lie beneath those seen on the middle to lower slope. They concluded that canyon capture explains this geometry, much as it explains drainage patterns on land. They argued in favor of the Daly (1936) model, say- 


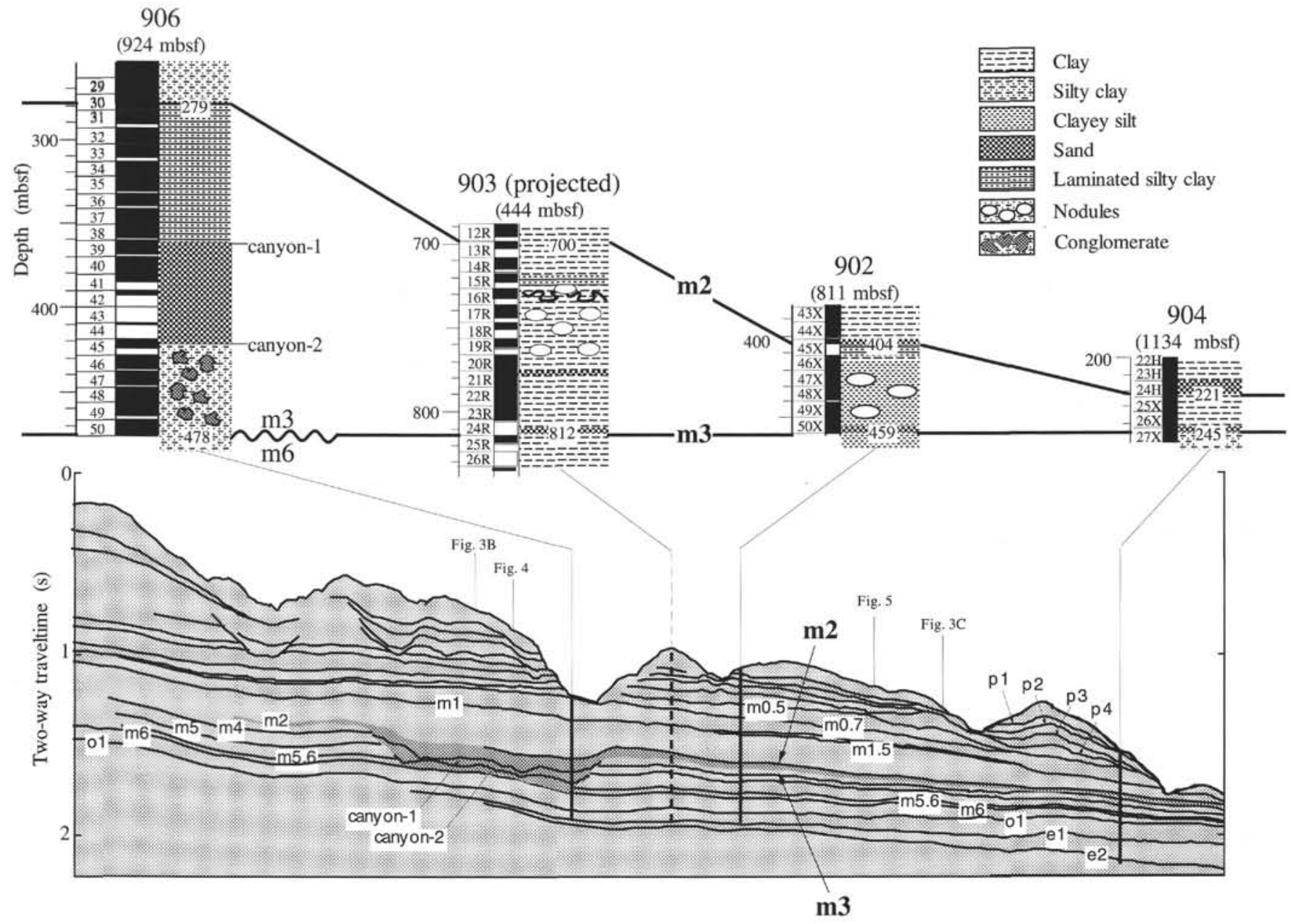

Figure 2. Original profile and line drawing interpretation of Line 1027 showing the Site 906 canyon (Neogene canyon "A") and the borehole correlations of key reflectors $\mathrm{m} 3$ and $\mathrm{m} 2$ to each of the Leg 150 sites drilled on the slope. Note the sharply defined southwest wall of this canyon, in contrast to the uncertain location of the corresponding northeast wall. The vertical exaggeration (VE) is approximately $4: 1$. The intersection with other profiles discussed in this report are designated by figure number. See Figure 1 for profile location.

ing that oversteepened shelf-edge sands are the abrasive agent that first carve canyons. As shelf-edge depocenters change through time, the locations of canyon heads change as well. The chance for slopecrossing turbidity currents to eventually encounter a preexisting depression increases downslope, and leads to the common occurrence of a reexcavated middle to lower slope canyon. They explained the small, straight canyons that lack any shelf indentation as relict canyons partially filled by Holocene drape on the uppermost slope.

\section{DATA AND METHODS}

\section{Seismic Profiles}

Ew9009 MCS lines 1005, 1006, 1026, 1027, and 1030 (Fig. 1) were essential to this mapping effort; no other profiles available to us so clearly reveal the buried canyon. The tie-in single-channel seismic (SCS) survey done aboard JOIDES Resolution before drilling at Site 906 (Mountain et al., 1994; Fig. 1) provided excellent data that helped determine the spatial dimensions of the canyon in the immediate vicinity of the drill site. The more extensive regional coverage of the Ew9009 SCS lines (Fig. 1) proved that the drilling target was indeed the oldest canyon for tens of kilometers in either direction along the slope.
The quality of the Ew9009 MCS profiles (Mountain et al., 1991) is attributed to the use of a tuned air-gun source ( 6 guns totaling 1350 in. $\left.{ }^{3}\right), 60$-fold stacking of short $(12.5 \mathrm{~m})$ hydrophone groups, and modest towing speeds ( $5 \mathrm{kt}$ or less), all of which contributed to a large signal-to-noise ratio that made true amplitude display possible. This preserved the dynamic range in reflector strength that is needed to make easy visual discrimination between strong and weak returns. By contrast, the Ew9009 SCS lines and the Leg 150 data were shot with a single water gun and a single-channel streamer towed at 6 to 8 kt. Time-varying gain adjustment was applied to these data to enhance deeply buried reflectors, but this reduced significantly the dynamic range of the data. Consequently, amplitudes of individual traces comprising these SCS profiles are artificially uniform, and this makes it difficult to distinguish some major reflecting surfaces from local stratal complications or noise.

The Ew9009 profiles, both MCS and SCS, were collected in 1990 before there was constant Global Positioning System (GPS) coverage along the East Coast. Consequently there were several gaps totaling $6-10 \mathrm{hr}$ in each day when transit satellite fixes connected by dead reckoning were the most reliable means of determining ship's position. Nonetheless, at each of the approximately 75 crossings of these profiles within the grid examined for this study (Fig. 1), acceptable agreements between traveltimes to as many as 10 sub-bottom reflec- 
tors could be made with arbitrary lateral adjustment of either track by no more than $500 \mathrm{~m}$. Full GPS coverage was available during Leg 150. However, the standard underway procedure was to record positions at irregular intervals that ranged from 1 to $5 \mathrm{~min}$ (the average interval between 966 positions was $2.9 \mathrm{~min}$ ). The standard practice for the Ew9009 navigation reduction, by contrast, was to log GPS fixes every $20 \mathrm{~s}$, apply a 9 -point running average to reduce jitter, and interpolate to the even minute. We suspect the less rigorous use of GPS-aided navigation on Leg 150 contributed to difficulties in correlating between profiles only during turns; at all other times seismic correlations could be made confidently both to other Leg 150 profiles and to the Ew9009 data.

The only significant discrepancy among the profiles we examined involved an apparent traveltime delay in the Leg 150 profiles. At every crossing of these lines with those of either the Ew9009 MCS or SCS data, everything was $140 \mathrm{~ms}$ too deep. The offset was so consistent that we felt comfortable ignoring it and adjusting the Leg 150 traveltimes to agree with those of Ew9009.

\section{Seismic-Borehole Correlations}

The nomenclature and seismic-borehole correlations of the reflectors defined by the Shipboard Scientific Party (1994b) are used in this report. The quality and line spacing of the profiles we have examined enable us to recognize and assign stratal significance to several more reflectors than reported in the foregoing reference. Future work may reveal that our seismic-borehole correlations require revised age or facies assignments, but we are confident that the profile-to-profile correlations developed here are internally consistent and locally correlatable.

To provide the reader with a seismic stratigraphic framework, despite the foregoing caveat, we show in Figure 2 the borehole correlations of the interval we think corresponds to the cut and fill strata found at Site 906 . For more detail, please refer to the site summary chapters in the Initial Reports volume (Mountain, Miller, Blum, et al., 1994). We assign reflector m6 to the top of a glauconite-rich siltstone/sandstone unit deposited near the Miocene/Oligocene boundary. These are the youngest sediments not eroded by the canyon at Site 906 . The acoustically stratified sequence of reflectors from m5.6 up to $\mathrm{m} 3$, all cut by the canyon, correspond to bathyal claystones with numerous intervals of sand-sized glauconite and quartz that account for the acoustic layering. Reflector $\mathrm{m} 3$ is correlated to the base of a glauconite sand bed at sites outside the canyon, and the age of this surface has been determined to be $13.5 \pm 0.5 \mathrm{~m}$.y. (Miller et al., this volume, see $\mathrm{Sr}$-isotope analyses). The $\mathrm{m} 3-\mathrm{m} 2$ interval outside the canyon generally grades upward to clayey silt or to claystone; the greatest amount of coarse material in this interval is at Site 902 , which is also the closest site to the buried canyon (Fig. 1). Reflector $\mathrm{m} 2$ is correlated to the base of another sand bed at Sites 902 and 904, and is assigned an age of $12.4 \pm 0.5 \mathrm{~m} . \mathrm{y}$. (Mountain, Miller, Blum, et al., 1994). Fifty-five meters of brecciated conglomerate capped by reflector canyon-2 comprises the basal unit within the canyon; the age and lithology of these rocks are identical to the adjacent wall rock sampled at the other slope sites. Sixty-two meters of poorly recovered, very clean quartz sand rests on these breccias and is topped by reflector canyon-1; no other Leg 150 site found facies equivalent to these sands. Eighty-two meters of laminated claystones comprise the interval between canyon- 1 and $\mathrm{m} 2$. A few meters of faintly laminated claystone immediately below $\mathrm{m} 2$ were cored at Site 902 and nowhere else.

\section{DISCUSSION \\ Neogene Canyon Drilled at Site 906}

The most obvious seismic expression of the canyon at Site 906 is the abrupt termination of reflectors $\mathrm{m} 3$ through $\mathrm{m} 5.6$ (Fig. 2). Typi- cally, the southwest wall is more easily recognized, in part because it appears to stand nearly vertical because of the large vertical exaggeration of the seismic displays we examined (from 4:1 to 17:1). The northeast wall is difficult to locate in many profiles because reflectors from chaotic fill within the canyon are easily confused with reflectors in the $\mathrm{m} 3$ to $\mathrm{m} 5.6$ section comprising this buried wall (Figs. 2, 3). Although chaotic fill is often observed along the floor of the canyon, as we will discuss, the corresponding sediments were deposited in at least two separate episodes: the first between the time of reflector $\mathrm{m} 3$ and $\mathrm{m} 2$, and the second between $\mathrm{m} 2$ and $\mathrm{m} 1.5$. The older fill is restricted to the up-canyon region landward of Site 906; the younger is found only down-canyon beginning about $7 \mathrm{~km}$ southeast of Site 906 . Additional chaotic fill of unknown age is observed in the extension of this canyon on the middle slope seaward of the $1400-\mathrm{m}$ isobath.

The high quality of line 1027 (Fig. 2) reveals two distinct reflectors within the fill at Site 906 (canyon-1 and canyon-2; Shipboard Scientific Party, 1994c). The lower reflector, canyon-2, marks the top of conglomeratic debris that is similar in age and facies to sediments cored between reflectors $\mathrm{m} 3$ and $\mathrm{m} 6$ at Site 902 and obviously exposed at one time along the canyon walls adjacent to and upslope from Site 906. The upper reflector, canyon-1, marks the top of clean turbidite sands that are unique to Site 906. Unfortunately, none of the SCS data can distinguish canyon-1 from canyon-2 (Fig. 3), and on these profiles we have been able to identify just one unit of canyon fill that probably includes both facies.

Reflector $\mathrm{m} 6$ is typically the youngest surface that can be traced beneath the canyon without interruption. The depth of erosion may increase downslope, but it is very subtle, if present at all. This stratigraphic limit to depth of erosion may be the result of lithologic control (e.g., well-indurated glauconitic sandstones at the m6 level, near the regionally disconformable Miocene/Oligocene boundary, may have been especially resistant to deeper erosion), but we place no strong importance on this observation.

Reflector $\mathrm{m} 2$ is the oldest feature that can be traced across the canyon and out onto the adjacent slope (Figs. 2, 3). At the upslope limit of available profiles, $\mathrm{m} 2$ dips only slightly below the canyon rim (Fig. 3A), demonstrating that at this location the canyon was nearly filled with $250 \mathrm{~ms}(\sim 270 \mathrm{~m})$ of pre-m 2 sediment. Downslope $3.5 \mathrm{~km}$ at Site 906 , roughly $100 \mathrm{~ms}(\sim 90 \mathrm{~m})$ of relief remained after $195 \mathrm{~ms}$ $(\sim 200 \mathrm{~m})$ of pre-m2 sediments were deposited (Fig. 2). The dip-oriented composite profile in Figure 4 shows that $\mathrm{m} 2$ laps out onto the canyon floor another $6 \mathrm{~km}$ downslope, though at this location the canyon still has $230 \mathrm{~ms}(\sim 200 \mathrm{~m})$ of incised relief (Fig. 3B). This seaward thinning of pre- $\mathrm{m} 2$ canyon fill is not the result of truncation by the $\mathrm{m} 2$ surface.

Chaotic fill that is stratigraphically above $\mathrm{m} 2$ and overlain by evenly bedded strata below reflector $\mathrm{m} 1.5$ fills the canyon another 2 km downslope (Fig. 3C). Had Site 906 been located here, samples would have revealed a long gap between canyon formation (m3) and canyon fill (conglomerates of unknown post-m2 age followed by probable turbidites close to the age of $\mathrm{m} 1.5$ ). Site 906 was located in a more favorable location for narrowing the age of canyon formation. Truncation of reflector $\mathrm{m} 2$ on the southwest rim of the canyon indicates erosion between the time of $\mathrm{m} 2$ and $\mathrm{m} 1.5$. At this same stratigraphic level a larger m2-m1.5 canyon formed $21 \mathrm{~km}$ toward the southwest (Fig. 3C).

The pattern of progressively younger sedimentary fill in the Site 906 canyon continues another $3 \mathrm{~km}$ downslope from the profile in Figure $3 \mathrm{C}$, to the limit of where the canyon can be recognized near the $1100-\mathrm{m}$ isobath. A probable remnant of the canyon can be seen at this location (Fig. 3D) but complex stratal patterns in the overlying Pleistocene make any Neogene tracings rather speculative. The entire Neogene section has been removed from the slope seaward of about the 1400-m isobath, and either Pleistocene siliciclastics are left in its place or Eocene carbonates are exposed directly on the seafloor from here to the base of the slope at about $2200 \mathrm{~m}$ water depth. The canyon remnant identified in Figure 3D is filled with Pleistocene debris, and 

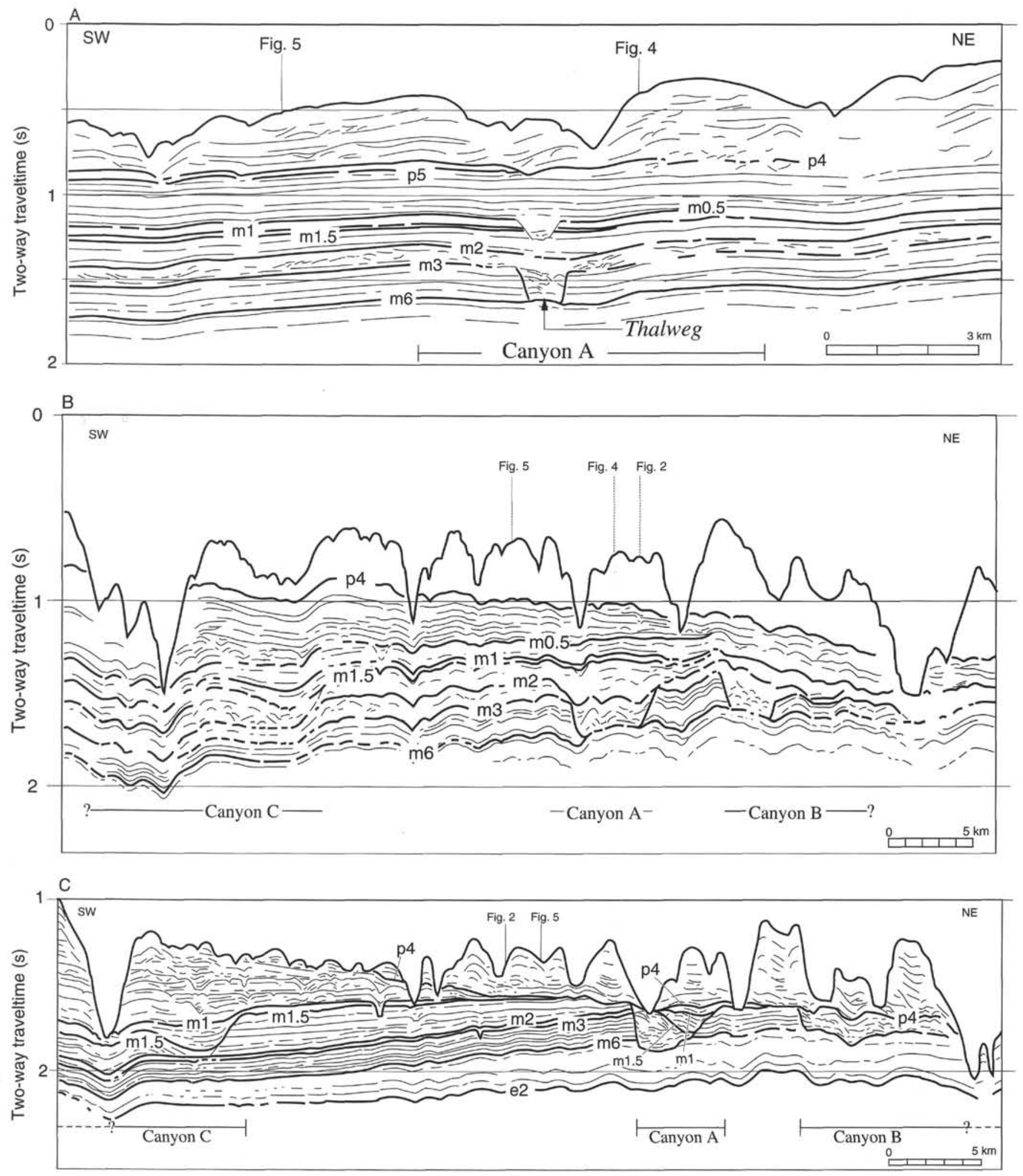

Figure 3. Original profiles and line drawing interpretations of four strike lines, oriented so that the viewer is looking upslope. VE is roughly 17:1. The intersections with other profiles discussed in this report are designated by figure number. See Figure 1 for all profile locations. A. Line 1026 on the uppermost slope; note that canyon "A" is completely filled by pre-reflector $\mathrm{m} 2$ sediments, and that there is a narrow inner "thalweg" to the canyon at this location. B. Unnumbered Ew9009 SCS line upslope of Site 906 where the pre-m 2 sediments partially fill the canyon; note the similarities with Neogene canyon "B" which is $5 \mathrm{~km}$ northeast. C. Unnumbered Ew9009 SCS line downslope of Site 906, beyond the pinchout of reflector m2 on the floor of canyon "A"; note the large Neogene canyon "C" to the southwest. D. Unnumbered Ew9009 SCS line downslope of Site 906, which is the farthest seaward that any remnant of Neogene canyons can be identified. 


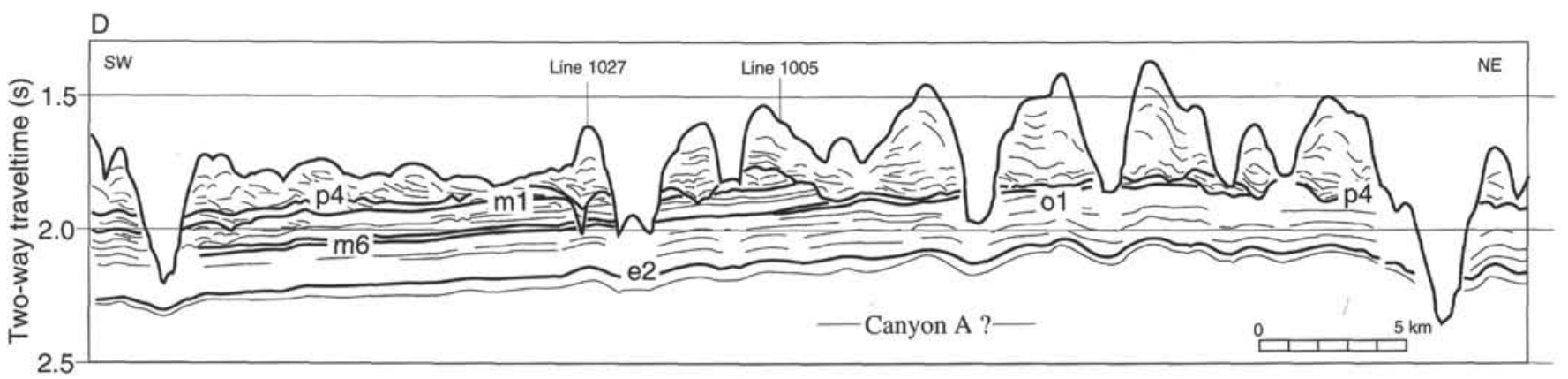

Figure 3 (continued).

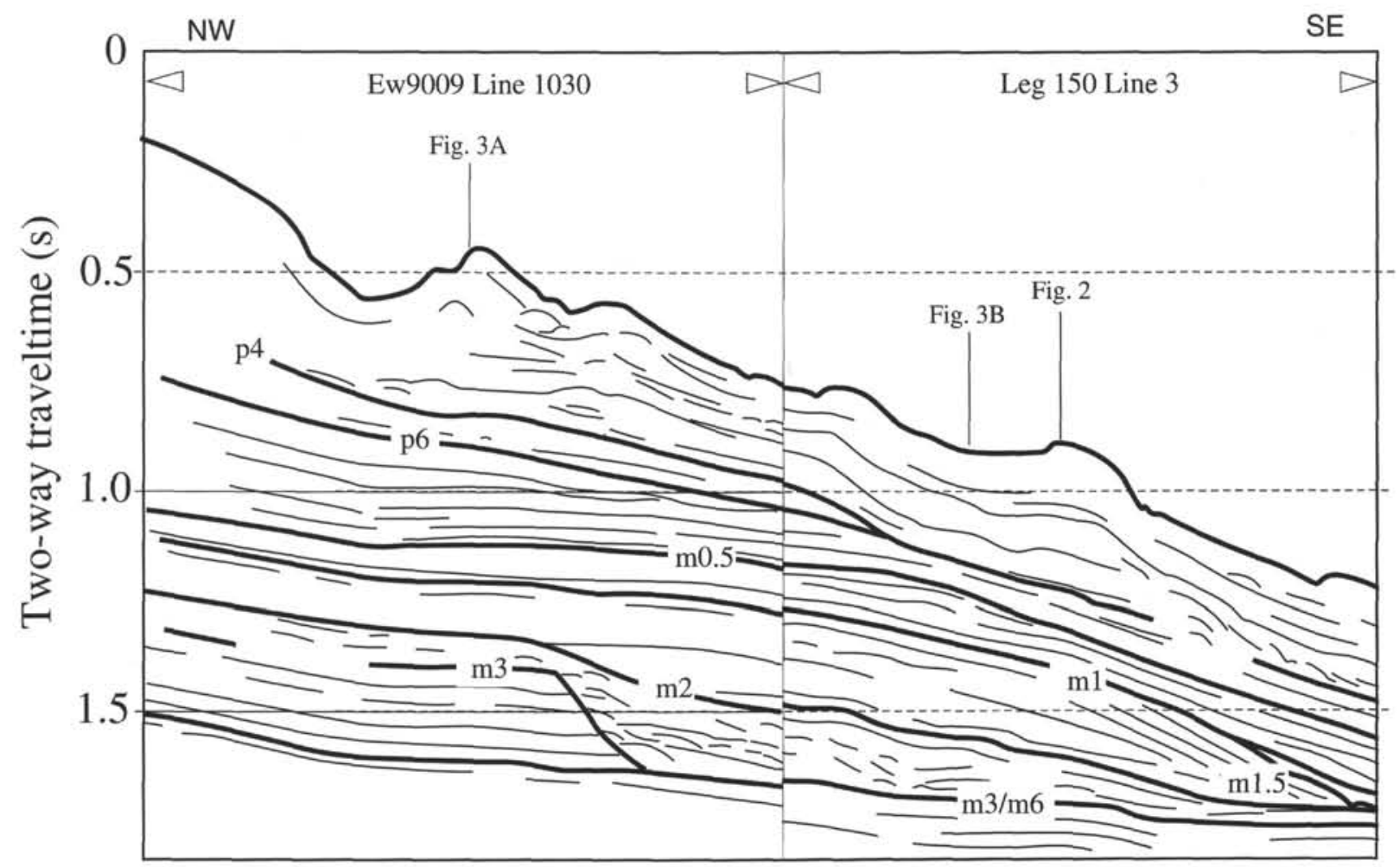

Figure 4. Line drawing composite interpretation of two dip-oriented profiles (Ew9009 MCS line 1030 and part of ODP Leg 150 SCS line 3) near the upslope limit of detection of the buried Neogene canyon "A" sampled at Site 906. The profile begins northeast of the buried canyon, and crosses into it where reflector $\mathrm{m} 2$ dips gently seaward and underlying irregular reflectors mark the infilling breccia. Note the downlap of the breccia and reflector $\mathrm{m} 2$ onto the floor of the canyon (reflector $\mathrm{m} 3 / \mathrm{m} 6$ ) roughly $7 \mathrm{~km}$ southeast of Site 906 . VE is approximately $4: 1$. See Figure 1 for profile location.

we speculate that either (1) the Neogene canyon was empty when this Pleistocene debris buried the feature without additional erosion, or (2) Pleistocene erosion deepened and widened whatever Neogene canyon was present. We prefer the latter choice because of the abrupt change in canyon morphology between the profiles in Figures $3 \mathrm{C}$ and 3D. Regardless of which is correct, the short downslope distance within which Pleistocene erosional surfaces (e.g., reflector p4; Fig. 5) intersect and strip off the Neogene suggest to us that at $\mathrm{m} 2$ time the canyon drilled at Site 906 continued farther seaward than can be seen now.

The precise upslope extent of the canyon is no more certain than is the downslope extent, but at least this limitation results from a lack of profile data, not from complex and unresolvable geology. Ew9009 line 1026 is the most landward profile on which the canyon can be identified with confidence (Figs. 1, 3A). Two Ew9009 SCS strike lines within $1 \mathrm{~km}$ upslope of this location do not penetrate to the depth of the canyon. Hopefully, data of sufficient quality will one day be collected to determine how far landward this feature extends and provide crucial information concerning its origin. To learn if it was formed by top-down abrasive processes or by bottom-up headward failure, one must determine whether or not the buried canyon connects to a buried valley system on the paleoshelf. If it did not, the origin must be attributed to any of several sediment failure mechanisms that occurred on the slope between $\mathrm{m} 3$ and $\mathrm{m} 2$ time. Considering the $\sim 200 \mathrm{~m}$ of sharp canyon relief on line 1026 , it seems entirely likely that the canyon does indeed continue much farther upslope than can be mapped at present.

At roughly $300 \mathrm{~m}$ water depth on line 1026 (Figs. 1, 3A) the canyon has a narrow thalweg roughly $0.5 \mathrm{~km}$ wide. The whole canyon, however, is considerably wider if measured at the rim implied by a 


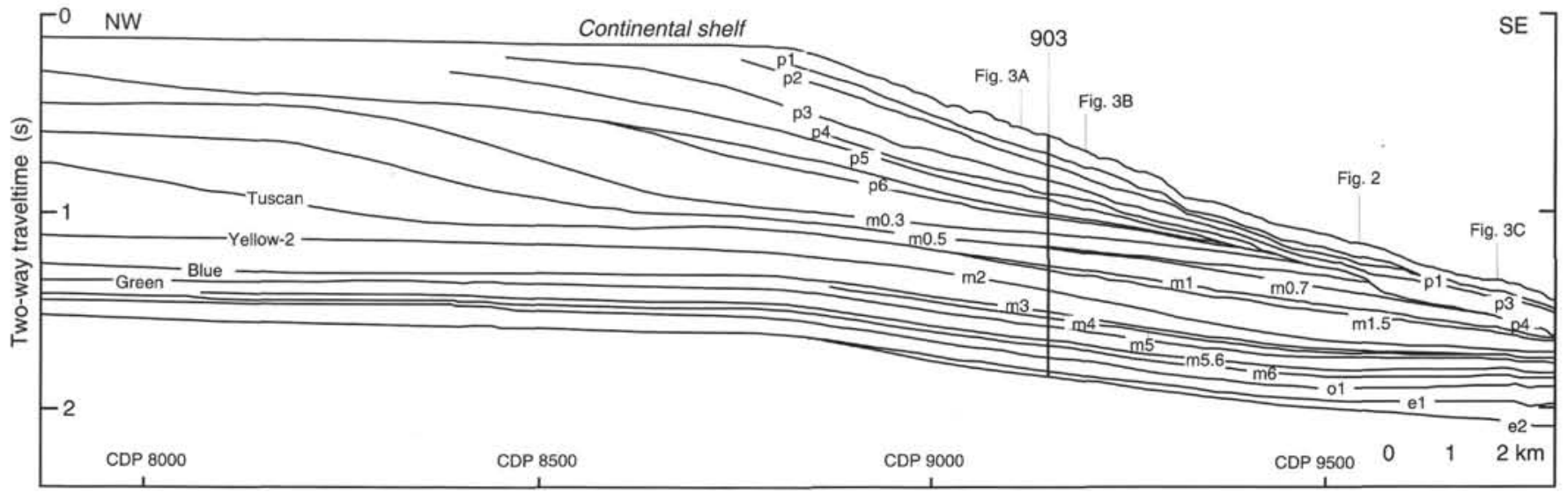

Figure 5. Line drawing interpretation of Ew9009 line 1005 approximately $5 \mathrm{~km}$ southwest of the buried Neogene canyon "A." Note the very small positive to perhaps even reverse dip of reflector $\mathrm{m} 6$ (close to the base of the buried canyon), the gentle dips of the generally parallel m5.6-m 3 sequence, the changes in dip of $\mathrm{m} 2$, and the very steep and truncating character of the Pleistocene cover (reflectors p4-p1). VE is approximately $4: 1$. See Figure 1 for profile location.

slight inward dip of reflector $\mathrm{m} 2$, though the exact location of the northeast rim is difficult to identify. Without more high-quality profiles, the character of the canyon beneath the uppermost slope is highly uncertain. Immediately downslope from Line 1026 the canyon widens abruptly to about $5 \mathrm{~km}$ and maintains this same width downslope for as far as it can be traced, though without an inner thalweg as seen on line 1026 .

In summary, the canyon maintains a rim-to-floor depth of 200 $290 \mathrm{~m}$ and a $5-\mathrm{km}$ width for the $13 \mathrm{~km}$ that it can be traced from the 300 to the $1100-\mathrm{m}$ isobaths. Over this distance the depth below sea level to the canyon axis increases by only about $60 \mathrm{~m}$, for an average gradient of 1:200. Without a doubt this gradient has been made artificially gentle since $\mathrm{m} 3$ time because of sediment compaction and flexural subsidence beneath the uppermost slope. On only the most landward profile that we have studied can an inner canyon thalweg be detected; all other profiles reveal a boxlike cross-section with no secondary structure within the main canyon. At about $15^{\circ}$, the southwest wall is typically steeper than the northeast wall, which is typically banked with debris and usually exhibits less than a $10^{\circ}$ inward dip. For comparison, along a comparable $13-\mathrm{km}$ stretch of the modern Berkeley Canyon overlying this Neogene example, the axial gradient is roughly $1: 11$, and the walls are $350-500 \mathrm{~m}$ high and stand at an angle of $10^{\circ}-15^{\circ}$. Measured between the interfluve peaks that divide it with adjacent canyons, Berkeley is uniformly $4 \mathrm{~km}$ wide across this same region.

\section{Other Neogene Canyons}

Strike line profiles demonstrate that the oldest Neogene canyon in this region (from here on called "canyon A") was sampled at Site 906 (Fig. 2). A similar feature ("canyon B") with the same inferred history is located $5 \mathrm{~km}$ toward the northeast (Fig. 3B, 3C), but because of more severe Pleistocene erosion and less ample seismic coverage in this area, details of this second canyon are less well known. It is difficult to be certain of the critical reflector correlations, but it appears that canyon B is wider than the one at Site 906 . A younger and still wider example ("canyon C") is found $21 \mathrm{~km}$ toward the southwest (Fig. 3B, 3C). This latter region beneath the northeast flank of Lindenkohl Canyon (Fig. 1) continued as a site of substantial accumulation into the late Miocene, and though comparable volumes of sediment may have been deposited near canyons A and B, evidence has since been removed by Pleistocene erosion. The southwest wall of canyon $\mathrm{C}$ was not crossed by profiles we studied.

There are several similarities among these three buried canyons. First, these are broad (from 5 to $>10 \mathrm{~km}$ wide) and comparatively flat-floored features, in clear contrast to most of the Pleistocene can- yons exposed on the seafloor. Second, all formed in late middle Miocene time: canyons A and B were first cut between the time that sediments equivalent to reflectors $\mathrm{m} 3$ and $\mathrm{m} 2$ were deposited ( 13.512.4 m.y.); canyon $\mathrm{C}$ was cut slightly later, between $\mathrm{m} 2$ and $\mathrm{m} 1.5$ time ( 12.4-?11.5 m.y.) (Mountain, Miller, Blum, et al., 1994). Canyons $\mathrm{A}$ and $\mathrm{B}$ eroded to or slightly below the level of reflector $\mathrm{m} 6$ (23-26 m.y.) and canyon C eroded to reflector $\mathrm{m} 2$. A third similarity is that seismic character shows that each canyon was filled as a result of more than one depositional process. The basal unit in canyon A is marked by chaotic reflectors that match the breccia sampled at Site 906; identical seismic character and inferred geologic significance are observed within canyon B (Fig. 3B, 3C). This infilling debris thins downslope to zero thickness in both canyons. The overlying interval between this breccia and the sand bed that correlates to reflector $\mathrm{m} 2$ likewise thins downslope, lapping out against the floor of canyons $\mathrm{A}$ and $\mathrm{B}$ just a few $\mathrm{km}$ downslope of the pinchout of the breccia. Similar seaward-thinning patterns are seen in basal sediments of the younger canyon $\mathrm{C}$, though the oldest fill that we have examined in profiles does not display the chaotic character apparent in the other two (Fig. 3B, 3C). Finally, all three buried canyons were the site of canyon rejuvenation between $\mathrm{m} 1.5$ and $\mathrm{ml}$ time. At Site 906 this unit was sampled at 111 to 157 meters below seafloor (mbsf) and comprises nodular, silty clay with sand-sized glauconite and quartz plus woody plant debris corresponding in profiles to a V-shaped incision roughly $750 \mathrm{~m}$ wide and $50 \mathrm{~ms}$ deep (Fig. 2). Approximately $3 \mathrm{~km}$ upslope of Site 906 , where canyon A was completely filled by $\mathrm{m} 2$ time, this younger canyon lies west of canyon A; within a few kilometers downslope of Site 906, however, topographic relief of canyon A remained at $\mathrm{m} 1.5$ time, and the younger canyon tracks downslope within canyon $\mathrm{A}$, along its east wall, apparently confined by this preexisting structure (Fig. 3C). Acoustic layering is characteristic of the $\mathrm{m} 1.5-\mathrm{ml}$ interval in all three canyons, suggesting the meter-scale sandy beds recovered from this interval at Site 906 are widespread turbidites.

A narrow, V-shaped canyon cuts into the $\mathrm{m} 1.5$ surface between canyons A and C (Fig. 3C). It can be traced across each profile in our data set from 500 to $1700 \mathrm{~m}$ water depth, and it neither changes significantly in width, depth of incision, nor downslope direction across this distance of $15 \mathrm{~km}$. DSDP Site 612 drilled into this canyon near the $1400 \mathrm{~m}$ isobath, and determined it is filled with $91 \mathrm{~m}$ of ?Miocene-Pliocene sand and mud that in turn is overlain by $44 \mathrm{~m}$ of homogenous Pleistocene mud. Several other canyons of similar character can be traced within the locally thick post-m1 section between Carteret and Lindenkohl Canyons. The consistent pattern of narrow, $\mathrm{V}$-shaped cross-section and straight downslope direction suggests each was formed by the top-down, abrasive turbidite process. We em- 
phasize the contrast in geometry and inferred character of sedimentary fill between these and canyons A, B, and C.

\section{Implications for Canyon Formation}

Based on the examples available in our study, we conclude that two classes of canyons formed during the middle to late Miocene offshore New Jersey. The larger but perhaps less common type (we note three examples) started with mass failure on the slope, and none of these lost its original flat-floored cross-section; the more common type formed by turbidity currents eroding narrower V-shaped cuts straight down the slope. In some cases Miocene or younger turbidity currents reoccupied previous canyons and partially or completely resculpted the original canyon. This multiphase history appears to have been more common on the middle and lower slope than on the upper. Our generalized interpretation is summarized in Figure 6.

Debris from the slope itself accumulated within the scars formed by sediment failure processes. In two of the three cases we studied (canyons A and B), the debris now constitutes the basal fill, and is observed on the most landward profiles we studied (at $300 \mathrm{~m}$ water depth, $\sim 3 \mathrm{~km}$ from the edge of the shelf); how much farther landward it can be traced is not certain. The majority of the debris, however, traversed the entire slope and came to rest on the continental rise. However, the unit laps out on canyon floors well before the base of the slope, suggesting that if we are correct about its genetic connection to rise deposits, one of two facts must be true: either there was a downslope increase of gradient that was too steep for deposition, or this basal unit was eroded from the middle to lower slope. Our seismic data does not have the resolution to evaluate the latter option.

Turbidites of clean, shallow-water quartz sand rest directly on the basal debris at Site 906; though we lack confirming seismic data, we presume similar turbidites rest on the basal debris of the other major canyons. The significance is that we detect no evidence that shallowwater turbidity currents actually carved the canyons; instead, everything supports the bottom-up mechanism that slope failure formed the troughs that were utilized by later turbidity currents. We do not have evidence to show that failure progressed upslope with time, but we suggest this was a likely, perhaps necessary, condition to connect these troughs with sources of shallow-water sands. The ultimate cause for these initial slope failures is not known.

A second unit of chaotic basal debris bounded by reflectors $\mathrm{m} 2$ and $\mathrm{m} 1.5$ nearly fills canyon A several kilometers downslope from Site 906 (Fig. 3C). This correlates to the more nearly layered fill at the bottom of canyon C (Fig. 3C). It is not understood why one seismic facies is chaotic, suggesting mass-flow mechanisms, while the other is layered, suggesting turbidity currents. This episode of canyon fill may correlate to debris flows at $620 \mathrm{mbsf}$ at Site 905 (Shipboard Scientific Party, 1994a). Although the volume of m2-m1.5 canyon fill looks substantially greater than the volume of fill resting immediately on m6 at Site 906, the difference may not be so large when one recognizes that this younger unit begins seaward of Site 906; landward of that location there was little to no canyon to fill at post-m2 time.

\section{CONCLUSIONS}

The main canyon drilled at Site 906 was formed at roughly $13.5 \pm$ $0.5 \mathrm{~m} . \mathrm{y}$., and no evidence yet confirms that this was a result of erosion by turbidity currents originating on the shelf. The oldest sediment we observed on this flat-floored canyon is debris, which we inferred to be shed from the adjacent walls. We conclude that sediment failure proceeded upslope and/or outward from an original point of failure, widening and/or lengthening the scar before it was reached by shallow-water material.

Debris similar in age and facies to the brecciated canyon fill at Site 906 was recovered at Site 905 . These latter sediments on the rise

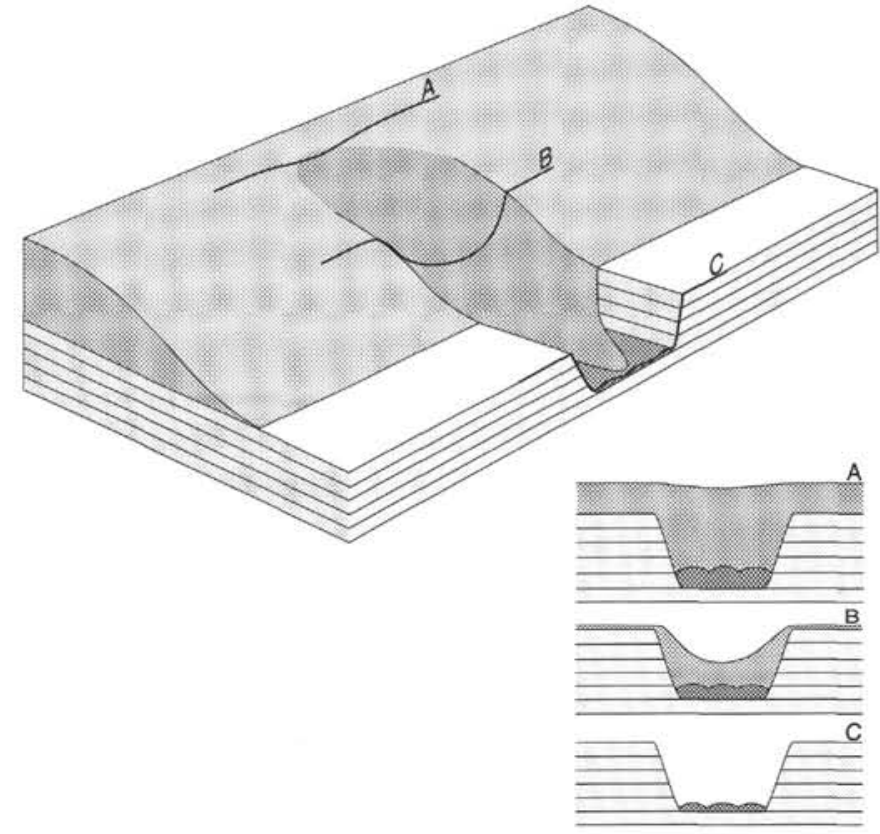

Figure 6. An isometric view of the slope as it may have looked at reflector $\mathrm{m} 2$ time. The canyon drilled at Site 906 is partially filled, and is crossed by hypothetical profiles A, B, and C. The oldest deposits on the canyon floor are debris from the widening and headward erosion of the original slump scar, and are overlain by shallow-water turbidites that demonstrate that in time the canyon connected with a source of shelf sands. The major volume of infilling sediment is laminated claystone between these sands and reflector $\mathrm{m} 2$. These sediments completely filled the canyon beneath today's uppermost slope; they thinned to zero thickness a few kilometers seaward of Site 906. A subsequent unit (not shown) of irregular debris followed by more turbidites and additional canyon incision followed (e.g., Fig. 3C). On the middle to lower slope (e.g., Fig. 3D), Pleistocene erosion appears to have reexcavated this canyon entirely.

did not include quartz sand beds that, if present, would suggest shallow-water contribution. It is possible that this debris was delivered to the rise through the canyon drilled at Site 906 . Furthermore, we suggest that these sediments at Site 905 provide additional evidence that the sand-rich turbidites following the debris flows took advantage of but did not form a Neogene slope canyon.

The clean turbidite sands resting on basal conglomerates at Site 906 probably reached the canyon through a river that emptied close to the canyon head. We suggest these sediments mark a time of rapid relative sea-level fall. Based on reasonable estimates of accumulation rates within the $82 \mathrm{~m}$ of laminated claystones between these sands and reflector $\mathrm{m} 2$, we estimate the age of this sea-level event is only slightly younger than reflector $\mathrm{m} 3$, probably between 13.4 and 13.0 \pm 0.5 m.y.

The upslope region of the canyon was the first to be filled. Our data shows that at today's $300-\mathrm{m}$ isobath this burial was completed at $\mathrm{m} 2$ time (12.4 \pm 0.5 m.y.) Pre-m2 sediments downlap onto the canyon floor $7 \mathrm{~km}$ seaward of this location, $3 \mathrm{~km}$ downslope of Site 906. Hence, at $\mathrm{m} 2$ time the canyon downslope of Site 906 still maintained as much as $250 \mathrm{~m}$ of relief.

Post-m2 fill of the canyon seaward of Site 906 began with another generation of chaotically deposited debris. Because the canyon in this region seaward of Site 906 does not widen downslope, we conclude that the post-m2 fill was not derived from the adjacent canyon walls.

Chaotic post-m 2 canyon fill seaward of Site 906 is capped by relatively evenly stratified reflectors that we speculate are turbidite sands of roughly reflector $\mathrm{m} 1.5$ age (?11.5 $\pm 1.5 \mathrm{~m} . \mathrm{y}$.) These, in turn, are eroded by reflector $\mathrm{m} 1$ (?11.0 $\pm 1.5 \mathrm{~m}$.y.) A thin remnant of equi- 
valent $\mathrm{ml} .5-\mathrm{m} 1$ strata was recovered at Site 906. Elsewhere along the New Jersey Margin (especially near Lindenkohl Canyon), ml.5 time is marked by major canyon erosion. For example, the canyon drilled at DSDP Site 612 matches the $\mathrm{m} 1$ event. At Site 906, it appears that both of these erosional episodes were accomplished by abrasive turbidity currents that took advantage of the depression left by an older and incompletely filled canyon.

The Neogene canyon widens considerably about $9 \mathrm{~km}$ seaward of Site 906 and is filled with a complicated assortment of reflectors that we cannot identify. We conclude that Pleistocene turbidity currents and mass-flow episodes broadened the Neogene canyon and then filled the remnant feature.

Beneath the upperslope landward of Site 906 and unaffected by Pleistocene processes, the width and wall angle of the Neogene canyon is similar to local Pleistocene canyons; its extraordinarily gentle axial gradient is an artifact of differential subsidence. That the Neogene canyon is roughly one-half the height of the modern Berkeley Canyon and flat-floored in cross-section (not V-shaped) suggests that it was never deepened by turbidity currents to the extent that has shaped Berkeley and most other slope canyons in this region.

We conclude that the canyon drilled at Site 906 was initiated by some undetermined mechanism of slope failure shortly after reflector $\mathrm{m} 3$ time, and only through headward erosion that eventually tapped a source did it become a conduit for shallow-water turbidity currents at reflector canyon- 2 time. The canyon was filled on the uppermost slope by $\mathrm{m} 2$ time, though considerable relief remained a few kilometers downslope. This relief led to the capture of subsequent turbidity currents that brought increasingly large volumes of abrasive sand across the slope. The connection with the overlying Berkeley Canyon is in this sense very direct on the middle slope below the $1400 \mathrm{~m}$ isobath. On the upper slope, however, Berkeley Canyon is not likely to have a genetic connection to this buried canyon, other than it provided a convenient "window" through which in the limited time we had during Leg 150 we could drill Site 906.

\section{REFERENCES}

Daly, R.A., 1936. Origin of submarine "canyons." Am. J. Sci., 31:401-420. Dana, J.D., 1863. A Manual of Geology: London (Truber).

Davies, T.A., Austin, J.A., Lagoe, M.B., and Milliman, J.D., 1992. Late Quaternary sedimentation off New Jersey: new results using 3-D seismic profiles and cores. Mar. Geol., 108:323-343.

Ewing, J., Le Pichon, X., and Ewing, M., 1963. Upper stratification of Hudson apron region. J. Geophys. Res., 68:6303-6316.

Farre, J.A., McGregor, B.A., Ryan, W.B.F., and Robb, J.M., 1983. Breaching the shelfbreak: passage from youthful to mature phase in submarine canyon evolution. In Stanley, D.J., and Moore, G.T. (Eds.), The Shelfbreak: Critical Interface on Continental Margins. Spec. Publ.-Soc. Econ. Paleontol. Mineral., 33:25-39.

Greenlee, S.M., Devlin, W.J., Miller, K.G., Mountain, G.S., and Flemings, P.B., 1992. Integrated sequence stratigraphy of Neogene deposits, New Jersey continental shelf and slope: comparison with the Exxon model. Geol. Soc. Am. Bull., 104:1403-1411.

Greenlee, S.M., and Moore, T.C., 1988. Recognition and interpretation of depositional sequences and calculation of sea level changes from stratigraphic data-offshore New Jersey and Alabama Tertiary. In Wilgus, C.K., Posamentier, H., Ross, C.A., and Kendall, C.G.St.C. (Eds.), Sea Level Changes: An Integrated Approach. Spec. Publ.-Soc. Econ. Paleontol. Mineral., 42:329-353.

Heezen, B.C., and Ewing, M., 1952. Turbidity currents and submarine slumps and the 1929 Grand Banks earthquake. Am. J. Sci., 250:849-878.

Horn, D.R., Ewing, M., Horn, B.M., and Delach, M.N., 1971. Turbidites of the Hatteras and Sohm Abyssal Plains, western North Atlantic. Mar. Geol., 11:287-323.

Knebel, H.J., Wood, S.A., and Spiker, E.C., 1979. Hudson River: evidence for extensive migration on the exposed continental shelf during Pleistocene time. Geology, 7:254-258.

Kuenen, P.H., 1937. Experiments in connection with Daly's hypothesis on the formation of submarine canyons. Leidse Geol. Meded., 8:327-351.

McGregor, B.A., Stubblefield, W.L., Ryan, W.B.F., and Twichell, D.C., 1982. Wilmington submarine canyon: a marine fluvial-like system. Geology, 10:27-30.
Miller, K.G., Melillo, A.J., Mountain, G.S., Farre, J.A., and Poag, C.W., 1987. Middle to late Miocene canyon cutting on the New Jersey continental slope: biostratigraphic and seismic stratigraphic evidence. Geology, 15:509-512.

Miller, K.G., and Mountain, G.S., 1994. Global sea-level change and the New Jersey margin. In Mountain, G.S., Miller, K.G., Blum, P., et al., Proc. ODP, Init. Repts., 150: College Station, TX (Ocean Drilling Program), 11-20.

Mountain, G.S., Lorenzo, J.M., and Fulthorpe, C.S., 1994. Underway geophysics. In Mountain, G.S., Miller, K.G., Blum, P., et al., Proc. ODP, Init. Repts., 150: College Station, TX (Ocean Drilling Program), 43-50.

Mountain, G.S., Miller, K.G., Blum, P., et al., 1994. Proc. ODP, Init. Repts., 150: College Station, TX (Ocean Drilling Program)

Mountain, G.S., Miller, K.G., Christie-Blick, N., Greenlee, S., and Devlin, W.J., 1991. High resolution MCS stratigraphy of Oligocene-Recent sequences, Mid-Atlantic continental shelf and slope. Geol. Soc. Am. Abstr. Progr., 23:A182.

Poag, C.W., 1985. Depositional history and stratigraphic reference section for central Baltimore Canyon trough. In Poag, C.W. (Ed.), Geologic Evolution of the United States Atlantic Margin: New York (Van Nostrand Reinhold), 217-263.

Poag, C.W., and Mountain, G.S., 1987. Late Cretaceous and Cenozoic evolution of the New Jersey continental slope and upper rise: an integration of borehole data with seismic reflection profiles. In Poag, C.W., Watts, A.B., et al., Init. Repts. DSDP, 95: Washington (U.S. Govt. Printing Office), 673-724.

Poag, C.W., and Sevon, W.D., 1989. A record of Appalachian denudation in postrift Mesozoic and Cenozoic sedimentary deposits of the U.S. middle Atlantic continental margin. Geomorphology, 2:119-157.

Poag, C.W., Watts, A.B., et al., 1987. Init. Repts. DSDP, 95: Washington (U.S. Govt. Printing Office).

Pratson, L.F., Ryan, W.B.F., Mountain, G.S., and Twichell, D.C., 1994. Submarine canyon initiation by downslope-eroding sediment flows: evidence in late Cenozoic strata on the New Jersey slope. Geol. Soc. Am. Bull., 106:395-412.

Robb, J.M., Hampson, J.C., Jr., and Twichell, D.C., 1981. Geomorphology and sediment stability of a segment of the U.S. continental slope off New Jersey. Science, 211:935-937.

Scanlon, K.M., 1982. Geomorphic features of the western North Atlantic continental slope between Northeast Channel and Alvin Canyon as interpreted from Gloria II long-range side-sonar data. Open-File Rep.-U.S. Geol. Surv.

Schlee, J.S., 1981. Seismic stratigraphy of Baltimore Canyon Trough. AAPG Bull., 65:26-53.

Shepard, F.P., 1981. Submarine canyons: multiple causes and long-time persistence. AAPG Bull., 65:1062-1077.

Shipboard Scientific Party, 1994a. Explanatory notes. In Mountain, G.S. Miller, K.G., Blum, P., et al., Proc. ODP, Init. Repts., 150: College Station, TX (Ocean Drilling Program), 21-42.

1994b. Site 905. In Mountain, G.S., Miller, K.G., Blum, P., et al., Proc. ODP, Init. Repts., 150: College Station, TX (Ocean Drilling Program), 255-308.

, 1994c. Site 906. In Mountain, G.S., Miller, K.G., Blum, P., et al., Proc. ODP, Init. Repts., 150: College Station, TX (Ocean Drilling Program), 309-357.

Shor, A.N., and McClennen, C.E., 1988. Marine physiography of the U.S. Atlantic margin. In Sheridan, R.E., and Grow, J.A. (Eds.), The Atlantic Continental Margin: Boulder, CO (Geol. Soc. Am.), I-2:9-18.

Spencer, J.W., 1903. Submarine valleys off the American coasts and in the North Atlantic. Geol. Soc. Am. Bull., 14:207-226.

Twichell, D.C., Knebel, H.J., and Folger, D.W., 1977. Delaware River: evidence for its former extension to Wilmington submarine canyon. Science, 195:483-485.

Twichell, D.C., and Roberts, D.G., 1982. Morphology, distribution, and development of submarine canyons on the United States Atlantic continental slope between Hudson and Baltimore canyons. Geology, 10:408412 .

Date of initial submission: 7 March 1995

Date if acceptance: 31 October 1995

Ms 150SR-022

This is LDEO contribution number 5495 . 